\title{
INCREASING FORMULATE AND TEST CONJECTURE MATH COMPETENCE AND SELF CONFIDENCE IN USING THE DISCOVERY LEARNING TEACHING MATH
}

\author{
Sylvia Rabbani ${ }^{1}$, Tatang Herman ${ }^{2}$ \\ ${ }^{1}$ STKIP Siliwangi Bandung, Cimahi, Indonesia \\ ${ }^{2}$ University of Indonesia Education, Bandung, Indonesia \\ ${ }^{1}$ sylviarabbani@gmail.com, ${ }^{2}$ tatangherman@upi.edu
}

\begin{abstract}
The main problem of this study is the lack of ability to formulate a conjecture of mathematics students in grade 5 elementary schools, lack of ability to test the conjecture of mathematics students in grade 5 elementary school and a low attitude of self-confidence of students Primary 5. This study uses quantitative and qualitative approach and methods of quasi and descriptive. The study population was the fifth grade elementary school students in District Ciparay Bandung regency. Sample consisted of 66 students divided into 33 classes of students in the various groups of experiment $V$-A and 33 students in the class $V-B$ as the control group. Instrument used comprising written tests on multiplication and division of fractions, and ratio and scale, attitude scale questionnaire of self-confidence, observation and interviews. Quantitative analysis was performed on average pretest and posttest ability to compose and mathematical conjecture test using the t test and Mann Whitney. Qualitative analysis were also conducted on the attitude scale questionnaire score self-confdence confirmed by observation and interview. The results pointed to an that mathematics learning by using discovery learning can improve students' mathematical formulate conjecture. Learning mathematics using discovery learning can also improve students' mathematical test conjecture. Self-confidence of students in the experimental class were obtained using discovery learning math learning is good.
\end{abstract}

Keywords: discovery learning, conjecture formulating competence, conjecture testing competence, self-confidence

\section{INTRODUCTION}

The Regulation of the Minister of National Education No. 22 of 2006 on the standard content of mathematics subjects for all levels of elementary and secondary education states that the objectives of mathematics subjects in primary schools are so that students are able to: (1) Understand mathematical concepts, explain the interconnection between concepts and apply concepts or logarithm, flexibly, accurately, efficiently, and appropriately in problem solving. (2) Using reasoning in patterns and traits, performing mathematical manipulations in generalizing, compiling evidence, or explaining mathematical ideas and revelations. (3) Solve mathematical problems that include the ability to understand problems, design models, interpret the solutions obtained. (4) Communicate ideas with symbols, tables, diagrams, or other media to clarify circumstances or problems. (5) Have an appreciation of the usefulness of mathematics in life, which has a curiosity, attention, and interest in learning mathematics, as well as a tenacious attitude and confidence in problem solving 
This is in line with Stacey's statement (Wijaya, 2012, p. 14) which mentions three knowledge and abilities that are the main characteristics of mathematical thinking: (1) deep mathematical understanding, (2) reasoning ability, and (3) heuristic strategy. Similarly, Leron (2004, p.26) defines mathematical thinking as the ability to build reasoning and idea communication. Based on the above opinion it can be concluded that reasoning is an important aspect in mathematical thinking.

In reasoning there are also some indicators that must be mastered by students. This is in line with Sumarmo (Shadiq, 2004, p.12), mathematical reasoning indicators on mathematics learning, among others, students can: Draw logical conclusions; Provide an explanation with models, facts, traits and relationships; Estimating answers and solution processes; Using patterns and relationships to analyze mathematical situations; Construct and test conjectures; Formulate the counter example (counter example); Following the rules of inference, checking the validity of the argument; Compose a valid argument; and Establish direct, indirect, and mathematical induction. The indicators of mathematical reasoning are very important for students to achieve, but one of the most important indicators is to construct and test conjectures.

Based on the observation of the learning process and the result of mathematics reasoning test in one of the primary schools located in Bandung District Ciparay Subdistrict, it is found that students are not accustomed to doing reasoning problems. The given questions already cover the 8 indicators of reasoning above. Students feel confused when given the questions. Most learners find it difficult to solve problems of mathematical reasoning presented in the form of story problems. Learners are confused in determining the right way or method to solve the problems of mathematical reasoning, especially on the problem with the indicators of composing and testing conjecture. This is because in that case the students must find their own mathematical conjecture, then compile it and test the truth of the conjectures.

In addition to cognitive abilities, affective abilities are also important to improve. One of them is the student's confidence in the knowledge and ability he has in working on the problem, solve problems, and follow the learning. This ability is better known as selfconfidence. This is in accordance with Sumarmo (2013) which states that self-confidence is a positive attitude that is an important part of learning, because this self-confidence reflects how one thinks something

According to interviews with some teachers of confidence (self confidence) is more emphasis on self-belief. This is in line with Dariyo (2004, p.15) simply defines self confidence as having self-belief. The high self-confidence of students will have an impact on the high confidence in what the students do. This can be seen when students can express opinions or 
findings that have been found and when students are confident with the answers of any mathematical problems and not easy to believe with answers that are not necessarily true friends.

With the confidence, the students will be more motivated and more like learning mathematics, so in the end expected mathematics learning achievement is also achieved more optimal. This is supported by several previous studies which reveal that there is a positive relationship between self-confidence in learning mathematics and mathematics learning outcomes (Hannula, 2004, Sehendri, 2012; Maryati, 2013; Yusmanto, 2015; Edison, 2015) means the results of mathematics learning for every student who has high self-confidence as well. Therefore, confidence needs to be owned and developed in every student.

The need for self-confidence held by students in learning mathematics was not accompanied by the facts. There are still many students who have low self-confidence. This is demonstrated by the TIMSS study in 2012 which states that on an international scale only 14\% of students have high self-confidence and high mathematical skills as well. While $45 \%$ of students included in the medium category and the rest included in the low category. The same is true for Indonesian students. Only 3\% of students had high self-confidence in mathematics, while $52 \%$ were in the category of students with moderate self-confidence and $45 \%$ were included in the category of students with low self-confidence.

One of the efforts that can be taken by teachers in improving the ability to arrange and test the conjecture and self-confidence of students in learning mathematics is to apply learning model that can develop and improve those abilities. One of the learning model that is expected to improve the ability to arrange and test the conjecture and self-confidence of students is the model of learning discovery learning. The discovery learning learning model is one of the learning models that involves the active participation of students in exploring and discovering their own knowledge as well as using it in problem solving. According to Fasco (in Mustafa, 2014, pp. 18) applying the discovery learning model will have the following effects, 1) provide an initial experience for student interest in asking questions, concepts, situations or ideas; 2) giving students a manipilative and material situation to start exploration roads; 3 ) provide a source of information for student questions; 4) providing materials and tools that trigger discovery-learning and student outcomes; 5) allow time for students to manipulate, discuss, try, fail and succeed; 6) provide guidance, assurance, and reinforcement for student ideas and hypotheses; 7) appreciate and encourage an acceptable solution strategy. A positive atmosphere that supports the best results for the ability to construct and test mathematical conjecture and self-confidence. 
Researchers try to use this Discovery Learning approach because this model is a learning one of the principles of directing students to find their own solution of the existing problems. With this kind of learning will familiarize the students to develop and test mathematical conjecture.

Based on the problems and phenomena that have been described previously, the authors intend to examine the effect of applying the Discovery Learning approach to the ability to arrange and test students' mathematical conjecture. For that researcher formulate research title that is Increasing Ability of Composing And Testing Conjecture Of Mathematics And Self Confidence Of Students In Mathematics Learning Using Discovery Learning.

\section{METHODS}

This study uses quasi-experimental methods and descriptions with quantitative and qualitative approaches. The research was conducted on the students at Ciparay Elementary School in Bandung Regency. The results of data collection were obtained through tests, questionnaires, observations, and interviews.

\section{RESULTS AND DISCUSSION}

1. The ability to arrange conjecture

The data analysis of the research findings shows that there is a very significant difference in the ability to construct mathematical conjecture between the control class and the experimental class. In general, based on the postes result score for the ability to construct mathematical conjecture, the students of the experimental class given the lesson with Discovery Learning showed better scores than the students in the control class given the learning by direct learning. Students in the experimental class obtained a mean score of 72.80 and control class 44.97 from a maximum score of 100 . Thus, from the average, the ability to construct students' mathematical conjecture in the experimental class is better than the students in the control class.

The results of data analysis performed on the pretest score and postes score showed that there was a significant difference in the postes score in the experimental class and in the control class. This is caused by the treatment (treatment) discovery learning. Rusefendi (in Sunaryo, 2013: 81) explains that the increase in postes score compared to pretesbelu is certainly due to the treatment, therefore it is necessary to test the ability of the initial ability of both classes together. Based on pretest score test, the ability to construct early mathematical conjectures of the experimental class is the same as the control class. Thus it can be concluded that the 
improvement of the ability to construct better experimental mathematics experimental class than the control class is caused by discovery learning treatment.

Based on the above explanation, in the experimental class with discovery learning treatment it helps students to find their own way to solve the existing mathematical problems. In this case the teacher only directs the student to solve the problems. In addition to the experimental class, it is also used to work on groups of LKS on mathematical issues concerning multiplication and fractional parts and scale and comparison. Groups were heterogeneously randomized, in which one group consisted of upper, middle and lower group. After the LKS is given, the students in the experimental class are accustomed to discuss the answers that have been discussed in front of the class.

Developing mathematical conjecture is included in one of the activities of non-routine mathematical thinking or known as high order mathematical thinking. This is in line with Sumarmo (2003, p. 4) suggesting that the ability to understand mathematical ideas in more depth, observing data and exploring the implied ideas, constructing conjectures, analogies and generalizations, logically reasoning, problem solving, mathematics and associate mathematical ideas with other intellectual activities are classified as non-routine mathematical thinking or high order (high order mathematical thinking).

In constructing mathematical conjecture we must provide learning that includes nonroutine mathematical thinking. This is in line with Riyanto and Rusdy's opinion that "learning with this conventional approach students solve many problems without a deep understanding, not exploring, finding traits, preparing and evaluating conjectures" (2011, p.23).

Based on the above explanation, in the experimental class with discovery learning it helps students to find their own way to solve the existing mathematical problems. In this case the teacher only directs the student to solve the problems. In addition to the experimental class, it is also used to work on groups of LKS on mathematical issues concerning multiplication and fractional parts and scale and comparison. Groups were heterogeneously randomized, in which one group consisted of upper, middle and lower group. After the LKS is given, the students in the experimental class are accustomed to discuss the answers that have been discussed in front of the class

Developing mathematical conjecture is included in the activities of non-routine mathematical thinking or known as high order mathematical thinking. This is in line with Sumarmo (2003, p. 4) suggesting that the ability to understand mathematical ideas in more depth, observing data and exploring the implied ideas, constructing conjectures, analogies and generalizations, logically reasoning, problem solving, mathematics and associate mathematical 
with high order mathematical thinking. In constructing mathematical conjectures we must provide learning that includes non-routine mathematical thinking. This is in line with Riyanto and Rusdy's opinion that "learning with this conventional approach students solve many problems without a deep understanding, not exploring, finding traits, preparing and evaluating conjectures" (2011, p.23).

This validation must later be complemented using deductive methods (Recio, Angel M. And Juan D, 2001, pp. 97) This validation should later be supplemented using the deductive method, but providing a certain logical consistency for the conjecture is done by means of intuitive procedures. In testing mathematical conjecture students should use deductive methods for logical reasons and appropriate procedures.

The ability to test the mathematical conjecture of students in the experimental class is good enough. This is because Discovery learning has several advantages compared to direct learning because discovery learning has a syntax of learning that can provide opportunities for students to develop the ability to examine mathematical conjecture, namely: the stage of stimulation (stimulation / stimulation), at this stage students are faced with problems that cause confusion, in order to arise desire to investigate itself. In addition, teachers can start learning activities by asking questions, providing math problems and other learning activities that lead to preparation of conjectures and test conjecture. Stimulation at this stage serves to provide a learning interaction condition that can develop and assist students in exploring the problem. The problem presented is a contextual problem that is assisted with concrete objects that exist in the environment. By manipulating concrete objects, students are expected to be stimulated in composing and testing mathematical conjectures.

So it can be concluded that the ability to test conjecture is very important to develop the ability of mathematical reasoning, especially for elementary school children. In testing conjecture, students can use concrete objects to help them. In addition students can also use the knowledge they already have in drafting the test dam conjecture. In this case the teacher acts as a facilitator and mentor.

\section{Self Confidence}

Another purpose of this research is to know the scale of self-confidence of students who acquire discovery learning. Self-confidence is a student's belief or self-confidence based on individual's knowledge and understanding of one's own ability. The self-confidence inductor in this research is showing a confident attitude with the capability possessed; showing independence in making decisions; show sufficient intelligence (mathematics); showing optimism, being calm and unyielding; have socialization skills; show a positive attitude in 
dealing with problems; able to adapt and communicate in various situations; and have the ability to think objectively, rationally and realistically.

The results showed that the average score of self-confidence scores of students in the discovery learning class is good enough. Viewed from table 4:39 shows that in general the average score of self-confidence scores of students is good enough. The findings identified that learning mathematics would work well if teachers could choose the method of learning and devise appropriate learning plans to develop that capability. Learning with discovery learning approach, teachers can train learning independence and develop student self-confidence. This is in line with Somakin (2011,) states that in order to develop student self-confidence in mathematics, mathematics learning can be done through methods or approaches that can train learning independence. With the independence of learning can develop a sense of selfconfidence in working on the problem and in following the math lesson. The results are also reinforced by the scale analysis of student self-confidence based on the indicator. Furthermore, based on the results of separate analysis of the indicators of self-confidence in this study looks at the attitude of self-confidence in the experimental class that received learning with discovery learning approach.

This can be seen from the average score questionnaire scale self-confidence attitude and student observation for this fifth indicator is quite high. From the results of interviews to students who have high self-confidence, they say that it can already socialize with family, friends, teachers and some parties around the environment. They do not hesitate to ask friends or teachers if they have difficulty in understanding mathematical material. In edition they are also not awkward if there are friends who do not understand asking them to teach him. While interviews to students with moderate self-confidence, they state they will ask teachers or friends who understand when they have difficulty in math materials, sometimes they feel ashamed to ask their teachers and friends. On the other hand, the results of interviews to students with low self-confidence, they rarely ask teachers or friends if they have difficulty in math materials. They also mentioned they were afraid of being laughed at by their friends if they asked a teacher or friend who could have the material. The role of the surrounding environment in self-confidence is very important, as expressed by Pierce and Gardner (2004, pp. 612). Communities, homes, schools, and colleagues are important for the growth of confidence. Sending positive messages to others is detrimental to the development of high selfesteem, while exposure to negative messages lowers confidence levels.

Confidence is also the basic capital to develop self-actualization. Dare to act and take the opportunity he faces. High confidence will affect the achievement that will be achieved. 
Meanwhile, low self-esteem causes bad things for students and affects their ability to deal with any problems. Confidence is based on a realistic belief in students' abilities. If the student feels inferior, then the student does not succeed in realizing the actual capability. They will avoid taking on new challenges. They will also limit their ability to give their best. So with a high confidence will be able to realize and apply his ability well so as to achieve the goal of achievement or desired learning outcomes. This is where the influence of confidence in student learning outcomes reinforce the belief in the abilities that exist in him, so hopefully will do the learning activities well and get good results

\section{CONCLUSION}

Based on the formulation of problem analysis results and discussion of the results of research as described in this study, then obtained the following conclusions:

1. There is a difference in the ability to build mathematical conjecture between students who learn with discovery learning learning with students who learn by direct learning. N-Gain score of students learning with discovery learning learning is higher than that of N-Gain students who learn by direct learning, thus the ability to construct mathematical conjectures that learn with discovery learning learning is better than that of students who learn by direct learning.

2. There is a difference in the ability to test mathematical conjecture between students who learn with discovery learning learning with students who learn by direct learning. N-Gain score of students learning with discovery learning is higher than that of N-Gain students who learn by direct learning, thus the ability to test the mathematics conjecture of students who learn with learning discovery learning better than students who learn by direct learning.

3. Students who have learned math with discovery learning have high self-confidence level

\section{REFERENCES}

Dariyo, A. (2004). Psikologi perkembangan remaja. Bogor: Ghalia Indonesia.

Depdiknas. (2007) Permendiknas Nomor 22 Tahun 2006 tentang Standar isi mata pelajaran matematika untuk satuanuntuk semua jenjang pendidikan dasar dan menengah. Jakarta: Depdiknas.

Hebaish, S. M. (2012). The correlation between general self-confidence and academic achievement in the oral presentation course. Theory and Practice in Language Studies, Vol. 2, No. 1, page. 60-65. 
Jacinta F.R. (2010). Memupuk rasa percaya diri. [Online] diakses dari http://www.e psikologi.com/dewasa/161002.htm [diunduh 11 mei 2016]

Kementrian Pendidikan dan Kebudayaan.(2013). Model pembelajaran penemuan (discovery learning). Jakarta.

Leron,U. (2004) Mathematical thinking and human nature: consonance and conflict. Technion-Israel Instituteof technology. procceding of th $28^{\text {th }}$ conference of the internasional group for the psychology of mathematics education, 2004. Technion, Israel institute of technology, vol.3 page 217-224.

Hannula. (2004). Development of understanding and self-confidence in mathematics, grades 5-8. Proceding of the 28 th Conference of The International Group for The Psychology of Mathematics Education. Vol 3 page 17-24, [Online] diaksesdarihttp://files.eric.ed.gov/fulltext/ED489565.pdf [diunduh 10 Mei 2016]

NCTM. (2000). Principles and Standards for School Mathematics. The National Council of Teachers of Mathematics, Inc.

Pierce, J. \& Gardner, D. (2004). Self-Esteem within the work and organisational context: a review of the organizationbased self- esteem literature. Journal of Management. 30 (5), page 591-622.

Polya, G.( 1953). Matemáticas y razonamiento plausible, Tecnos, Madrid [1966]. proof', in A. Olivier and K. Newstead (eds.).Proceedings of the 22th International Conference of PME (Vol. 2), Stellenbosch, South Africa, pp. 345-352.psychology of learning and motivation San Diego: Academic Press. (Vol. 43, pp. 215-266).

Recio, A. M. \& Juan D. (2001). Institutional and personal meanings of mathematical proof. Educational Studies in Mathematics 48,2001, page 83-99.

Ruseffendi. E.T.(1991) Pengantar kepada membantu guru mengembangkan kompetensinya dalam pengajaran matematika untuk meningkatkan CBSA. Bandung: Tarsito.

Shadiq, F. (2007). Penalaran atau reasoning perlu dipelajari para siswa di sekolah?.[online] diaksesdarihttp://prabu.telkom.us/2007/08/29/penalaran-atau-reasoning [diunduh 11 Mei 2016].

Shadiq, F.(2004).Pemecahan masalah, penalaran dan komunikasi.Disampaikan pada DiklatInstruktur/Pengembang Matematika SMA Jenjang Dasar Tanggal 6 s.d. 19 Agustus 2004 di PPPG Matematika. Yogyakarta: Departemen Pendidikan Nasional Direktorat Jenderal Pendidikan Dasar dan Menengah Pusat Pengembangan Penataran Guru (PPPG) Matematika Yogyakarta.2004,hal.2. 
Sumarmo, U. (2003).Berfikir matematik tingkat tinggi: apa, mengapa, dan bagaimana dikembangkan pada siswa sd dan sm dan mahasiswa calon guru. MakalahSeminar Nasional dan Lokakarya, FKIPUniversitas Sriwijaya, Palembang 20-21Agustus 2003

Widyantini, T.(2012). Penerapan model pembelajaran langsung dalam mata pelajaran matematika SMP/MTs. Pusat Pengembangan Dan Pemberdayaan Pendidik Dan Tenaga Kependidikan (PPPPTK) Matematika.

Wijaya. A (2012). Pendidikan matematika realistic: suatu alternative pendekatan pembelajaran matematika. Yogyakarta: Graha Ilmu. 